\title{
KAMPUNG KULINER SEHAT DI KEMANG
}

\author{
Ferdian $^{1)}$, Suwandi Supatra ${ }^{21}$ \\ 1) Program Studi S1 Arsitektur, Fakultas Teknik, Universitas Tarumanagara, Ferdianrusli@yahoo.com \\ 2) Program Studi S1 Arsitektur, Fakultas Teknik, Universitas Tarumanagara, ybhan@gmail.com
}

\begin{abstract}
Abstrak
Pola hidup kurang sehat, serta kecenderungan konsumsi makanan yang tidak sehat/ junk food menjadi penyebab utama terjadinya obesitas. Third Place merupakan tema utama dari bahasan penelitian ini. Maka isu yang dibahas pada penelitian ini yaitu "Bagaimana sebuah Third place dapat mendukung pola hidup sehat?". Lokasi proyek berada di Jl.Kemang raya, Jakarta Selatan yang merupakan kawasan yang terkenal akan kuliner. Lokasi tapak berada didekat perkantoran, bank, restoran cepat saji, dan toko furniture.Tujuan utama dari proyek ini yaitu menjadi sebuah tempat yang memfasilitasi masyarakat untuk menjalankan pola hidup sehat melalui makanan sehat. Hal ini juga bertujuan mendukung program Sustainable Development Goals perihal kesehatan yang baik dan kesejahteraan. Metode penelitian yang dilakukan pada penelitian ini dimulai dengan menemukan fasilitas/ program yang bertujuan menyelesaikan masalah dari sebuah kawasan. Kemudian dilanjutkan dengan proses mendesain fasilitas yang akan menghasilkan besaran ruang dalam proyek ini. Hasil penelitian ini yaitu mendesain bangunan berupa Kampung Kuliner Sehat di Kemang/ Healthy Culinary Village in Kemang. Proyek ini memiliki program utama berupa Sharing Kitchen, Fresh Market, Dessert Bar, Restaurant, Cooking Class, Gym yang bertujuan meningkatkan pola hidup sehat dan mengurangi tingkat obesitas melalui kuliner/ makanan sehat. Memberi kontribusi kepada lingkungan dengan menyediakan Third place sebagai wadah untuk bersosialisasi bagi masyarakat di kawasan proyek tersebut.
\end{abstract}

\section{Kata kunci: Kemang; kuliner; sehat; third place}

\begin{abstract}
Unhealthy lifestyles, and the tendency of consumption of unhealthy foods/ junk food are the main causes of obesity. Third Place is the main theme of this research discussion. The issue discussed in this study is "How can a third place support a healthy lifestyle?" The location of the project is on Jl. Kemang raya, South Jakarta which is known for culinary. The site is located near offices, banks, fast food restaurants and furniture stores. The main purpose of this project is to become a place that facilitates the community to living a healthy lifestyle through healthy food. This project supports the Sustainable Development Goals program regarding good health and well-being. The research method used in this study started by finding facilities / programs aimed at solving problems in an area. Then proceed with the process of designing a facility that will produce an amount scale of space in this project. The results of this research is designing a building in the form of a "Healthy Culinary Village in Kemang / Healthy Culinary Village in Kemang". This project have 5 main program in the form of Sharing Kitchen, Fresh Market, Dessert Bar, Restaurant, Cooking Class, Gym which aims to improve healthy lifestyles and reduce the level of obesity through culinary / healthy food. This project contributing to the environment by providing a Third place as a place to socialize for the community in the project area.
\end{abstract}

\section{Keywords: culinary; healthy; Kemang; third place}

\section{PENDAHULUAN}

Manusia merupakan makhluk sosial, yang artinya tidak dapat hidup sendiri tanpa bantuan orang lain. Selalu membutuhkan interaksi dengan sesamanya dalam hidupnya. Interaksi ini 
muncul dalam kegiatan yang terjadi sehari-hari dalam kehidupan bersama. Dimulai dari kehidupan berkeluarga, pendidikan, pekerjaan, maupun kegiatan lainnya. Menurut Ray Oldenberg dalam Great good place $(1989,1991)$, Kehidupan berkeluarga, tempat tinggal disebut sebagai first place. Berikutnya kegiatan penting lainnya dalam kehidupan seseorang, yang pada umumnya merupakan pekerjaan, terdapat dalam sebuah tempat yang disebut second place. Selanjutnya kegiatan yang merupakan bentuk dari interaksi sosial diwadahi dalam sebuah tempat yang disebut third place.

Sebuah third place yang menjadi wadah bagi kegiatan masyarakat untuk berkumpul/ berkomunitas menjadi tempat yang bersifat publik. Pada umumnya, tempat publik yang mewadahi suatu kegiatan tertentu akan didominasi, serta dikelola oleh sekelompok orang yang menjalankan kegiatan tersebut. Kegiatan ini kemudian berlanjut dengan adanya biaya pengelolaan, yang menyebabkan adanya komersialisasi didalam berbagai kegiatan lain. Kegiatan komersial yang dilakukan pada sebuah ruang akan menyebabkan pergeseran sifat publik menjadi privat.

Pada masa ini, kebutuhan masyarakat akan wadah/ tempat interaksi sosial yang bersifat publik mulai bergeser ke tempat yang bersifat privat. Hal ini dikarnakan minimnya tempat publik yang layak dan mampu mewadahi kebutuhan masyarakat akan kegiatan yang merupakan bentuk dari interaksi sosial tersebut. Oleh karena itu, dengan memperhatikan masalah tersebut, proyek yang akan dibuat akan menjadi tempat yang mewadahi kebutuhan masyarakat akan third place. pemilihan program yang terdapat dalam bangunan akan menyesuaikan kebutuhan masyarakat di kawasan tempat proyek ini dibangun.

\section{KAJIAN LITERATUR}

\section{Third place}

Third place adalah sebuah tempat yang bertujuan untuk memenuhi kebutuhan manusia untuk berkumpul/ berkomunitas yang bersifat informal dan publik. Tempat ini menjadi bagian dari bentuk kota dari kehidupan sehari-hari masyarakat. Menurut Ray Oldenberg sebuah third place harus memiliki karakteristik sebagai berikut:

a. Daerah Netral

Sebuah kota membutuhkan daerah netral dimana orang-orang dapat berkumpul. Tempat dimana orang-orang dapat datang dan pergi secara bebas. Manusia ingin menikmati hubungan dengan manusia lain, tetapi tidak akan merasa nyaman apabila berada di area privat seperti rumah, dimana kehidupan pribadi seorang individu yang merupakan privasi dapat dilihat oleh individu lain.

b. Level

Level disini merupakan sebuah istilah yang berarti menurunkan atau menghapuskan segala perbedaan posisi atau jabatan yang dimiliki seseorang agar semua orang menjadi sama rata. Dengan adanya kesamarataan, third place dapat diakses oleh siapapun secara umum tanpa kriteria yang resmi. Dengan tujuan berbagai macam individu dapat membaur bersama dan bersosialisasi.

c. Percakapan

Hal yang menandakan keberadaan sebuah third place adalah adanya perbincangan yang baik, bersemangat, berwarna dan menyenangkan. Inilah aktivitas utama yang terjadi dalam sebuah third place. Kunci utama nya adalah percakapan, dan apapun yang dapat mengganggu berjalannya percakapan, dapat merusak third place.

d. Aksesibilitas

Akses ke dalam lokasi harus mudah. Third Place harus dapat menerima kedatagan pelanggan kapanpun, khususnya saat pelanggan tidak harus berada di tempat kerjanya. Aktivitas yang terjadi di Third Place lebih fleksibel, tidak ada perencanaan atau penjadwalan tertentu seperti yang harus dilakukan di tempat kerja atau rumah. Hal lain yang berhubungan dengan waktu adalah lokasi. Apabila lokasi Third Place dipindahkan ke tempat 
yang jauh dari tempat tinggal seorang individu, maka untuk mencapai tempat tersebut menjadi lebih sulit dan pelanggan tempat tersebut akan berbeda dan tidak dikenali oleh individu tersebut.

e. Adanya Pelanggan Tetap

Hal yang lebih menarik bagi seorang pelanggan untuk datang ke Third Place bukanlah soal manajemen tempat tersebut, tetapi sesama pelanggan lainnya. Pelangganlah yang membuat tempat ini menjadi semakin hidup dan memberikan karakter pada Third Place. Walaupun sambutan dari pemilik tempat juga penting, namun yang lebih penting adalah adanya sambutan dari pelanggan lain yang menerima pengunjung yang datang.

\section{Isu dan permasalahan}

Pada masa ini, kebutuhan masyarakat akan wadah/ tempat interaksi sosial yang bersifat publik mulai bergeser ke tempat yang bersifat privat. Hal ini dikarnakan minimnya tempat publik yang layak dan mampu mewadahi kebutuhan ini. Stephen Carr (1992) pada public places-urban spaces, the dimension of urban design, menyatakan bahwa adanya lima kebutuhan dasar yang dapat memenuhi kepuasan pengguna ruang publik :

a. Kenyamanan; merupakan syarat mutlak untuk keberhasilan sebuah ruang publik. Seberapa lama pengguna berada di ruang public merupakan salah satu indikator dari kenyamanan.

b. Relaksasi; relaksasi termasuk dalam kenyamanan secara psikologi, yang lebih berkaitan dengan tubuh dan pikiran.

c. Keterikatan pasif; keterikatan secara pasif dengan lingkungan dapat menimbulkan perasaan santai namun berbeda dengan pemenuhan kebutuhan yang dikaitkan dengan lokasi atau keberadaan ruang publik tersebut.

d. Keterikatan aktif; meliputi pengalaman langsung dengan tempat dan orang-orang yang berada di tempat tersebut

e. Penemuan; mempresentasikan keinginan untuk mendapatkan pemandangan dan pengalaman baru yang menyenangkan ketika mereka berada di suatu ruang publik.

Kelima faktor tersebut disediakan oleh ruang publik yang dimiliki oleh privat. Hal ini menyebabkan masyarakat cenderung untuk memilih ruang publik yang dimiliki oleh pihak privat sebagai tempat berkumpul menggantikan tempat publik yang seharusnya merupakan third place. Namun, ruang publik yang dimiliki oleh pihak privat tidak dapat menggantikan sebuah third place dalam beberapa aspek berikut:

- Jam operasional

Ruang publik yang dimiliki oleh pihak privat biasanya memiliki jam operasional dari jam 10 pagi hingga 10 malam.

- Setiap tempat berbayar

Setiap kegiatan yang dilakukan, dimulai dari parkir, makan, menonton bioskop semuanya bersifat berbayar atau memiliki ketentuan tertentu.

- Jenis kegiatan/ fungsi

Pada umumnya kegiatan yang dilakukan di ruang publik yang dimiliki oleh pihak privat cenderung bersifat konsumtif yang dilakukan oleh pihak pemilik tempat untuk mendapat keuntungan.

Berbagai jenis kegiatan yang ada pada ruang publik yang dimiliki oleh pihak privat ini yaitu:

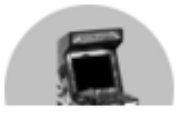

Wahana

Permainan

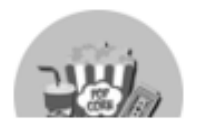

Pertunjukkan

Bioskop

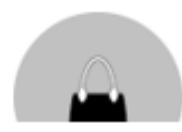

Berbelanja

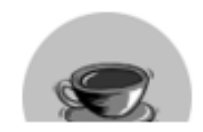

Nongkrong di Cafe

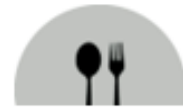

Makan di

Restoran 
Seluruh kegiatan yang dapat dilakukan sehari-hari oleh masyarakat ini bersifat konsumtif. Pola perilaku konsumtif masyarakat tidak terlepas dari berbagai masalah yang berkaitan dengan kesehatan.

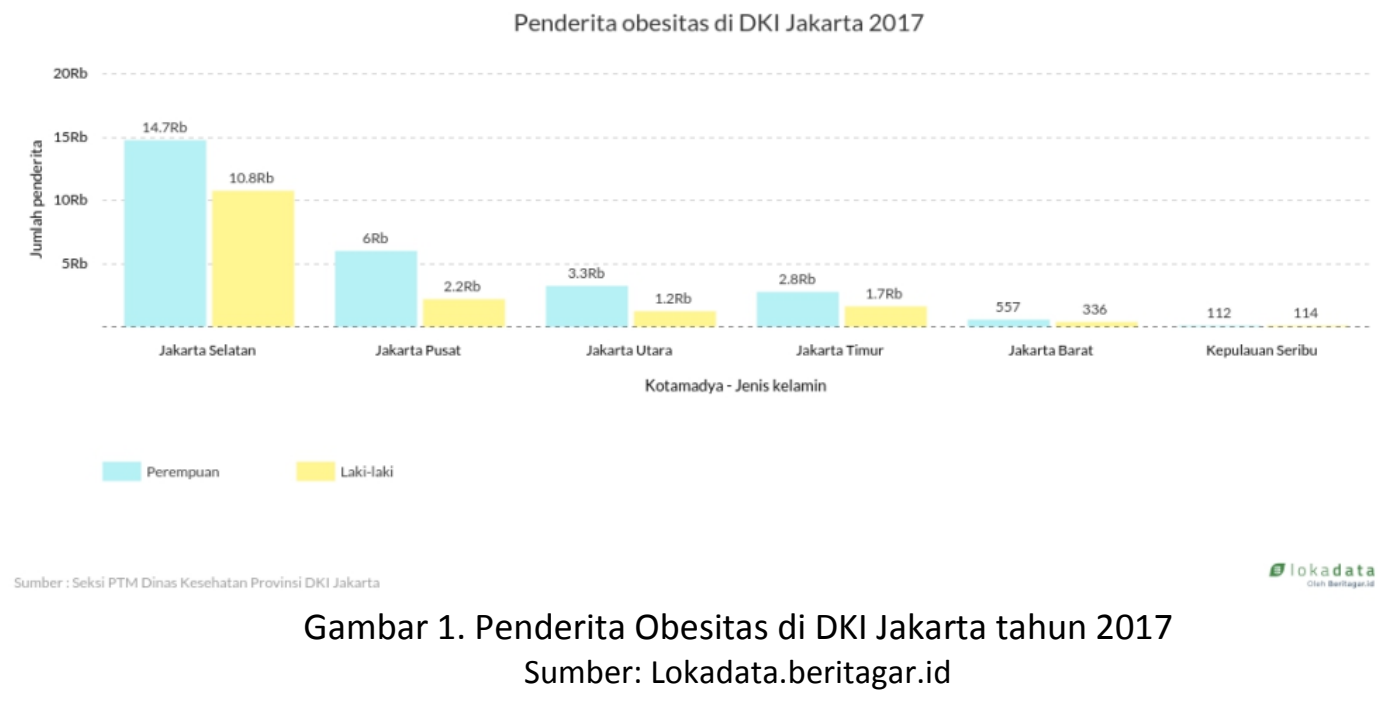

Penderita obesitas di Jakarta terbanyak merupakan penduduk kawasan Jakarta Selatan. Hal ini disebabkan pola hidup kurang sehat, serta kecenderungan konsumsi makanan yang tidak sehat/ junk food. Perilaku individu untuk membuat pilihan yang sehat hanya dapat terjadi dalam lingkungan yang mendukung dengan pilihan makanan sehat yang terjangkau. Menurut Mary story (2007) dalam Creating Healthy Food and Eating Environments: Policy and Environmental Approaches menyatakan bahwa beberapa hal yang mempengaruhi seorang individu dalam melakukan pemilihan makanan dan perilaku makan yaitu:

\section{A. Rumah}

Secara kolektif, penelitian menunjukkan bahwa makanan sehat yang tersedia dan mudah diakses di dalam rumah cenderung meningkatkan asupan makanan sehat di kalangan remaja dan keluarga.

B. Sekolah

Lingkungan sekolah dapat memiliki dampak besar pada asupan makanan anak-anak dan remaja karena seorang anak menghabiskan waktu setengah harinya di sekolah, dengan jadwal istirahat dua kali untuk memakan makanan berat dan makanan ringan di sekolah setiap hari

C. Tempat kerja

Karena sekolah adalah untuk anak-anak, tempat kerja adalah tempat yang ideal untuk menjangkau orang dewasa. Lingkungan tempat kerja memiliki pengaruh bagi perubahan perilaku individu.

D. Supermarket

Kehadiran toko makanan, dan ketersediaan produk yang sehat di toko-toko itu, merupakan kontributor penting bagi pola makan sehat di antara penghuni lingkungan. Toko bahan makanan memainkan peran utama dalam pembelian makanan, rumah tangga rata-rata melakukan dua kunjungan ke supermarket per minggu. Beberapa penelitian telah menemukan hubungan antara akses ke supermarket dan asupan makanan yang lebih sehat. 


\section{Sejarah Healthy food}

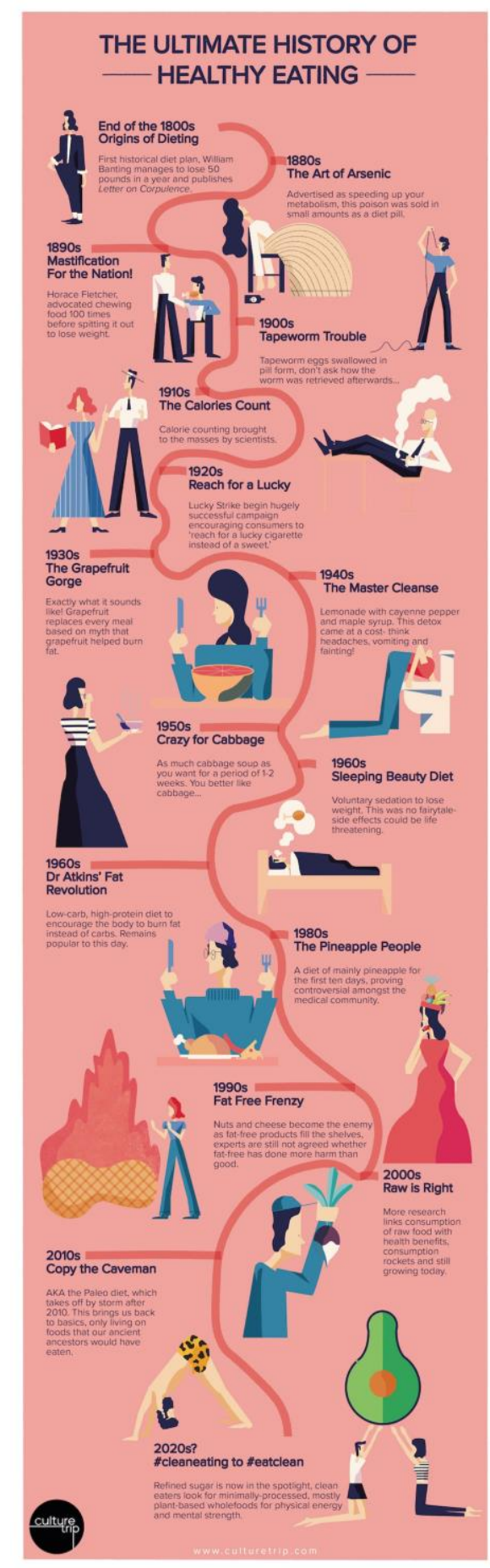

Gambar 2. History of Healthy Eating Sumber: culturetrip.com

Pada awalnya makanan sehat diperkenalkan oleh William Banting pada tahun 1800an, ketika dia berhasil menurunkan berat badan sebesar 50 pound dalam waktu 1 tahun dan memperkenalkan program dietnya melalui buku Letter On Corpulence. Seiring perkembangan jaman semakin banyak ditemukan berbagai cara untuk menurunkan berat badan. Pada saat ini proses menurunkan berat badan dengan memakan makanan sehat dengan cara mengurangi kadar gula pada makanan, menggunakan bahan organik, serta memasak dengan proses yang seminimal mungkin untuk tetap menjaga kesegaran serta kandungan dari bahan makanan. (Johnson, 2017) 


\section{Healthy food}

Pada dasarnya makanan yang sehat merupakan makanan yang menggunakan bahan makanan yang segar, baik, serta diolah dengan cara yang benar dan tepat. Menurut Inge Tumiwa-Bachrens, penulis buku Eating Clean. Berikut cara untuk memasak makanan yang baik:

1. Menghindari memasak dengan cara digoreng (terlebih deep fried), dan utamakan cara yang sehat, yaitu kukus, tumis, dan panggang dengan sedikit minyak.

2. Jangan terlalu banyak menggunakan butter atau margarin, dan utamakan pemakaian minyak sehat untuk memasak, seperti olive oil dan minyak kelapa.

3. Jangan terlalu banyak menggunakan garam dan utamakan garam yang beryodium untuk memasak.

4. Jangan terlalu lama memasak sayuran, karena hal ini dapat merusak kandungan nutrisi dan mengubah rasa dari sayuran itu sendiri.

5. Jangan gunakan tepung putih dan semua bahan makanan yang terbuat dari tepung putih.

6. Menghindari penggunaan MSG dan bumbu-bumbu dapur yang menggunakan MSG untuk memasak. Gunakanlah berbagai bumbu segar maupun kering seperti jahe, kunyit, bawang putih, daun mint, daun peterseli, dan sebagainya, karena bumbu-bumbu ini memiliki banyak manfaat baik untuk kesehatan tubuh.

7. Menggunakan bahan-bahan alami yang kaya serat, air, dan nutrisi. Utamakan yang berbahan organik, karena kandungan obat, hormon, dan pestisidanya cenderung lebih sedikit, serta gunakan sayuran dan buah-buahan lokal, karena tidak menggunakan lilin atau bahan kimia lainnya sebagai pengawet.

8. Menghindari penggunaan berbagai jenis gula dan bumbu-bumbu dapur yang mengandung gula. Sebagai alternatif, gunakan buah asli atau bawang bombai untuk rasa manis pada masakan.

9. Jangan berlebihan dalam memasak santan, baik dalam hal jumlah maupun waktu pemanasannya. Utamakan selalu santan alami, karena santan dalam kemasan sudah pasti mengandung bahan pengawet.

10. Membuang semua kulit atau lemak yang terdapat pada ayam atau daging sebelum dimasak.

\section{METODE}

\section{Proses menemukan fasilitas}

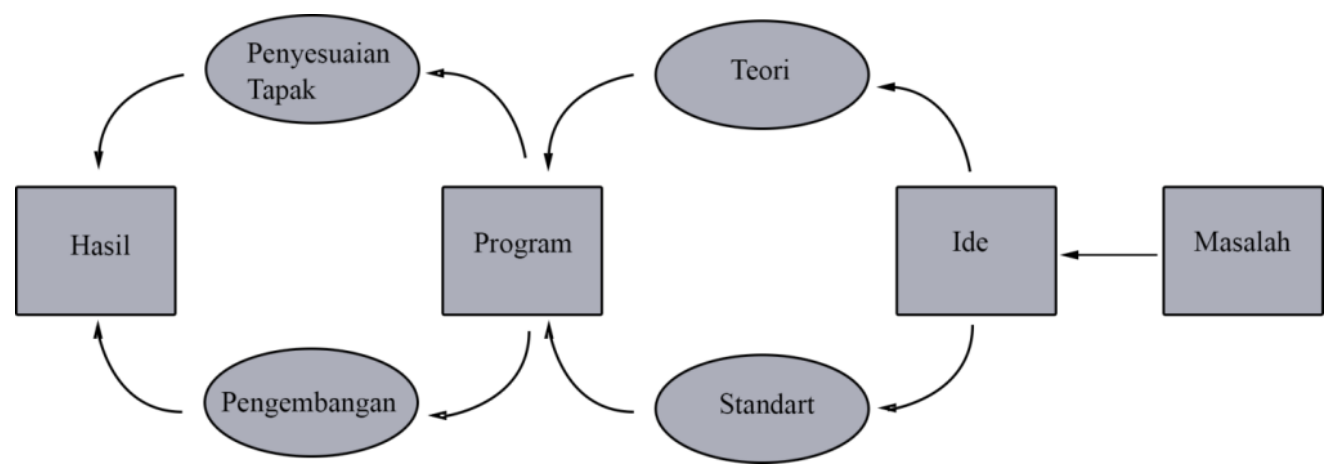

Gambar 3. Diagram proses menemukan fasilitas

Sumber: Penulis, 2019

Proses desain dimulai dengan menemukan permasalahan. Masalah ini tidak memiliki arah, tidak berbentuk. Lebih lanjut, hal ini bersifat subjektif untuk persepsi dan prasangka seseorang. Kemudian dilanjutkan dengan memberikan ide berupa cara untuk penyelesaian masalah. Ide ini kemudian harus disesuaikan dengan teori maupun standart dengan tujuan menjadikan ide bersifat objektif. Ide ini kemudian dikembangkan menjadi sebuah program yang akan diwujudkan kedalam aktivitas/ kegiatan. Kemudian program yang sudah dihasilkan 
akan dideduksi dan disesuaikan dengan kebutuhan tapak, sebelum akhirnya menjadi sebuah hasil berupa ruang/ tempat dengan isi kegiatan yang bertujuan menyelesaikan masalah. Hasil dari gagasan mengenai penyelesaian masalah tersebut kemudian dituangkan kedalam proses merancang bangunan, sebagai berikut:

\section{Proses mendesain}

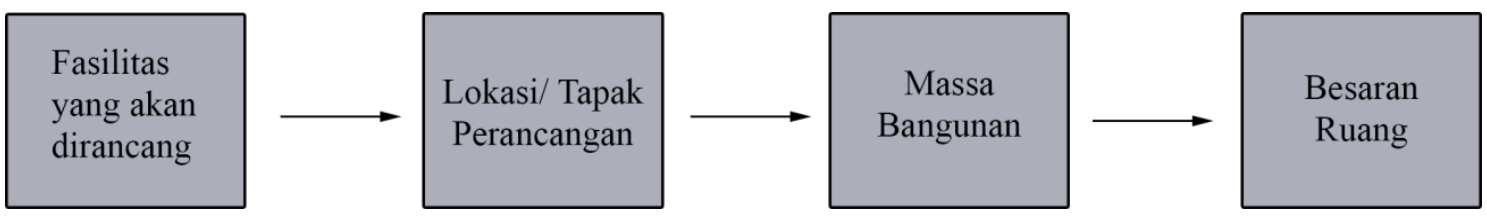

Gambar 4. Diagram proses mendesain Sumber: Penulis, 2019

\section{A. Fasilitas}

Terdiri dari daftar kegiatan di dalam gedung. Unsur-unsur ini tidak berdiri secara independen tetapi dalam hubungan fungsional yang berkaitan satu sama lain, baik kuantitatif dan kualitatif.

B. Tapak dan Lingkungan

Seringkali bangunan hanya didesain sebatas di tapak. Pada intinya, tapak ini bukanlah sesuatu yang terpisah tetapi merupakan bagian dari masalah. Yang lebih penting adalah merancang topografi tanah, plot sempit antara dua bangunan tinggi, kemiringan bertahap di lereng bukit, dan tekstur visual situs.

C. Massa bangunan

Bentuk dari sebuah bangunan, sebagai sebuah respon dari cara untuk menghadapi/ mengatasi masalah yang ada, baik dari bentuk tapak, maupun mewadahi fungsi didalamnya.

D. Besaran Ruang

Ruang bukan sesuatu yang disuntikkan ke dalam desain pada akhir proses, Ruang adalah bagian dari desain, merupakan bagian dari bangunan yang menciptakan suasana yang dapat dirasakan oleh pengguna.

Seluruh komponen ini merupakan proses desain. Hal tersebut adalah faktor utama yang memberikan arahan dalam proses mendesain dalam menyelesaikan masalah. Dalam proses ini setiap tahapan memberikan proses timbal balik terhadap tahap lain, hingga membentuk wajah akhir berupa hasil desain.

\section{DISKUSI DAN HASIL}

Proyek ini dinamakan Kampung Kuliner Sehat di Kemang/ Healthy Culinary Village in Kemang dengan konsep dasar Healthy foods and eating environment as a third place yang berisi program yang mendukung kebiasaan memakan makanan sehat serta menjadikan bangunan ini berkontribusi positif terhadap kawasan. 


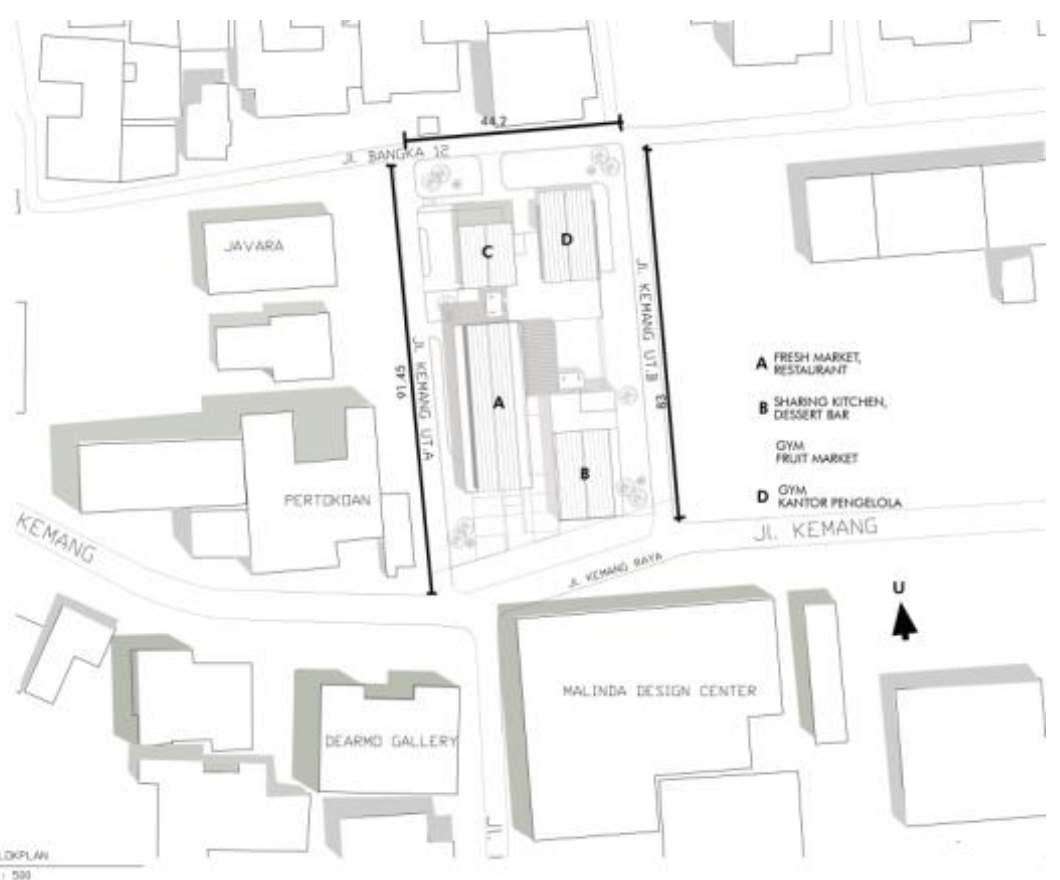

Gambar 5. Lokasi Tapak

Sumber: Penulis, 2019

Proyek ini berada di Jl. Kemang raya bersebrangan dengan Malinda Design Center. Kawasan kemang dikenal dengan pusat kuliner di Jakarta Selatan, sehingga posisi site sesuai dengan fungsi bangunan

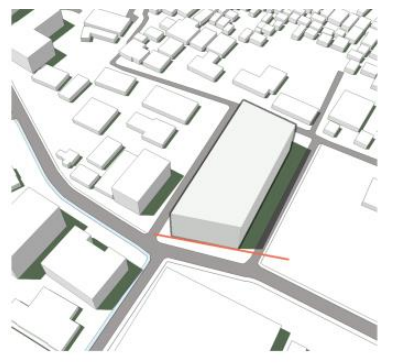

PEMBENTUKAN MASSA

MASSA DIBUAT MENGIKUTI BENTUK TAPAK

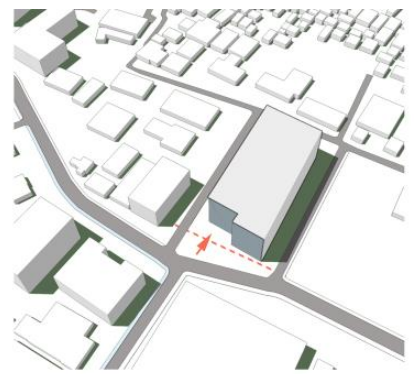

MAIN ENTRANCE

MAIN ENTRANCE DIBUAT MENGHADAP ARAH JALAN, SERTA BAGIAN DEPAN UTAMA

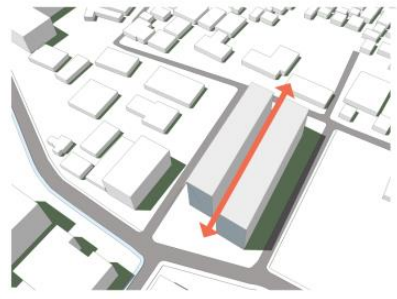

AKSIS UTAMA

MASSA DIBUAT MENGIKUTI BENTUK TAPAK

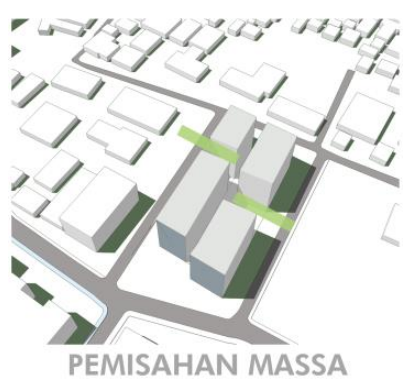

PEMISAHAN MASSA

PEMBAGIAN MASSA BERDASARKAN ZONING SERTA BERTUJUAN UNTUK MENCIPTAKAN OUTDOOR SPACE

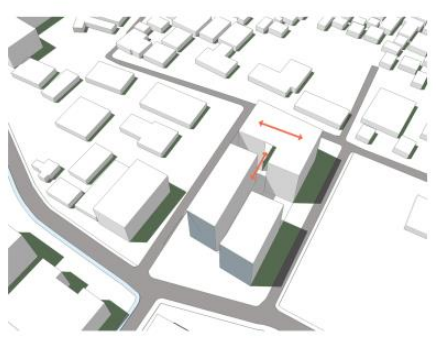

KONEKTIVITAS DAN AKSES

MASSA BAGIAN BELAKANG DIHUBUNGKAN DAN DISATUKAN
UNTUK UNTUK MEMPERMUDAH

Gambar 6. Pengolahan Gubah

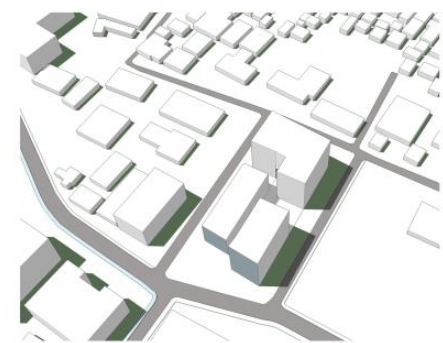

SIRIKULASI DALAM BANGUNAN SIRKULASI DALAM BANGUNAN DIBUAT BERDASARKAN HUBUNGAN ANTAR RUANG DALAM BANGUNAN

Sumber: Penulis,2019 
Setelah melakukan pengolahan gubahan massa, proses berikutnya yaitu memasukkan program ke dalam bangunan yang disesuaikan dengan kesesuaian fungsi serta hubungan antar ruang. Kemudian menyesuaikan karakteristik ruang setiap program dengan konsep third place yang ingin dibangun.

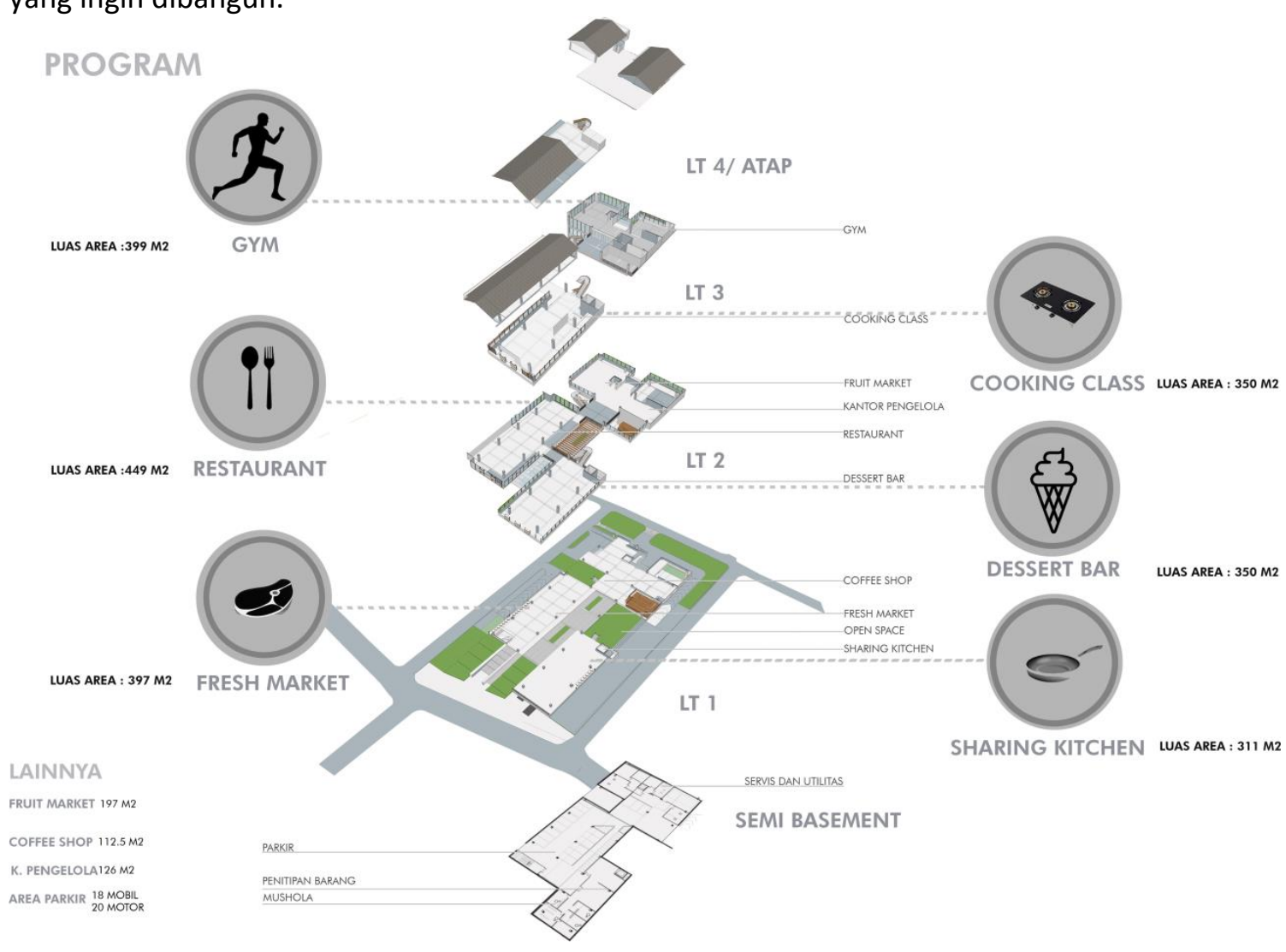

Gambar 7. Program

Sumber: Data pribadi

Penggunan fasad kisi-kisi pada tampak bangunan merupakan impelementasi dari konsep semioutdoor pada ruang didalamnya, hal ini juga didukung dengan penggunaan jendela hidup untuk memaksimalkan pengudaraan dan pencahayaan alami
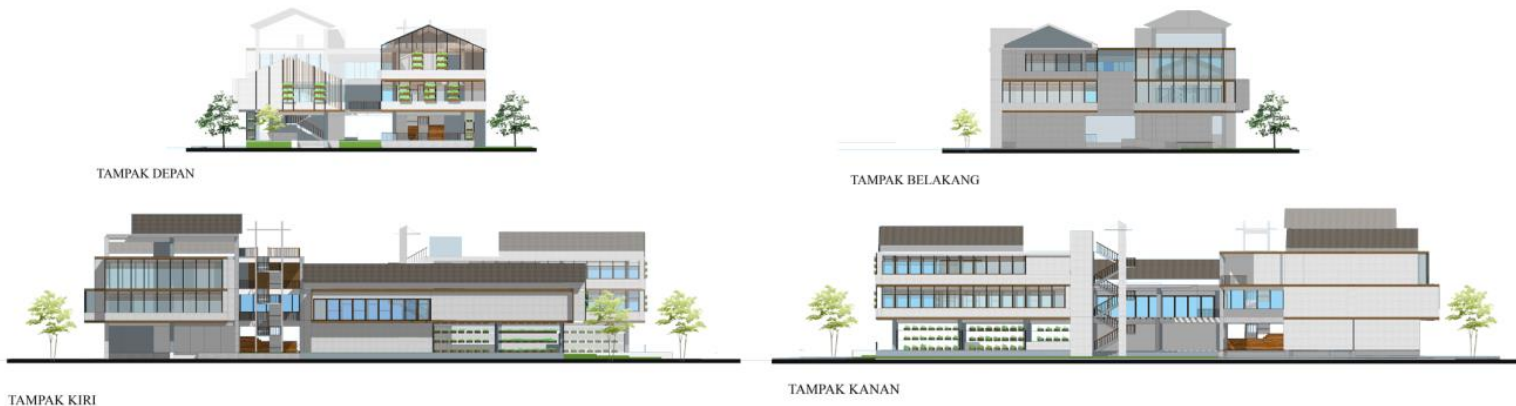

Gambar 8. Fasad bangunan

Sumber: Penulis, 2019

Berikut ini adalah gambaran visual dari bangunan pada eksterior dan interior, konsep semioutdoor diterapkan pada ruang-ruang utama yang menjadi thirdplace pada bangunan, seperti sharing kitchen, dessert bar, dan cooking clas, penggunaan material serta warna dan tanaman mendukung konsep healthy eating sebagai program utama pada bangunan. 


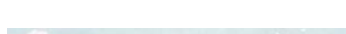
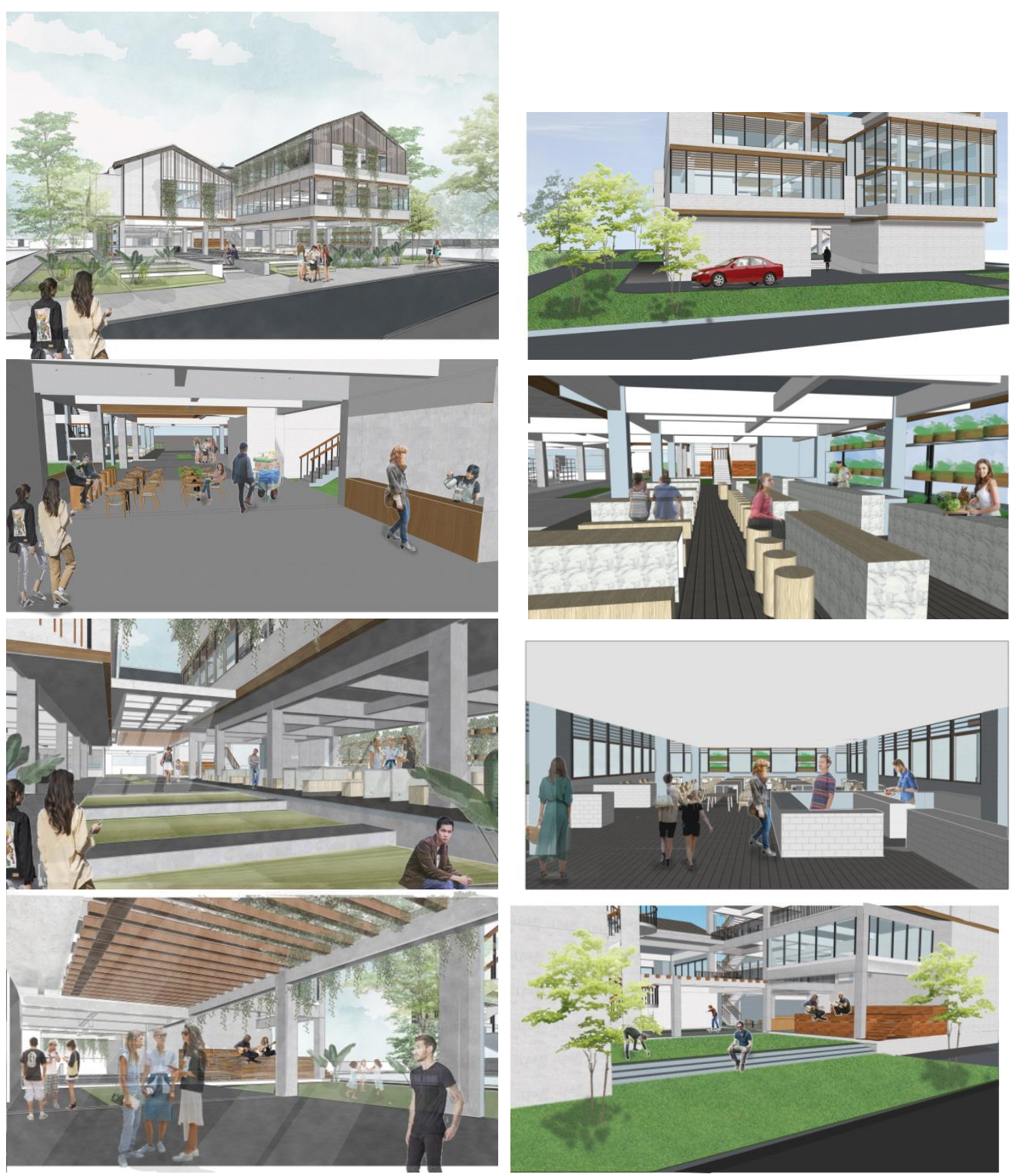

Gambar 9. Perspektif Eksterior dan Interior bangunan Sumber: Penulis, 2019

\section{KESIMPULAN DAN SARAN Kesimpulan}

Proyek Healthy Culinary Village ini dibuat berdasarkan isu dan masalah berupa kebutuhan masyarakat akan wadah/ tempat interaksi sosial yang bersifat publik mulai bergeser ke tempat yang bersifat privat. Hal ini dikarnakan minimnya tempat publik yang layak dan mampu mewadahi kebutuhan masyarakat akan kegiatan yang merupakan bentuk dari interaksi sosial tersebut. Program Healthy Culinary ini termasuk dalam kategori komersial, yang merupakan sebuah third place untuk kawasan. Fasilitas utama pada program ini dibagi menjadi beberapa fungsi yang berkesinambungan yaitu Sharing Kitchen, Fresh Market, Dessert Bar, Restaurant, Gym. Proyek ini memiliki tujuan untuk menjadi sebuah Thirdplace dalam kawasan ini, serta mendukung sustainable development goals perihal kesehatan yang baik dan kesejahteraan 


\section{Saran}

Pengolahan ruang dapat lebih dimaksimalkan sesuai dengan karakteristik program/ fungsi yang ada didalamnya

\section{REFERENSI}

Bachrens, I. T. (2016). Eating Clean: 20 Langkah Mudah Membiasakan Makan Sehat. Jakarta: Kawan Pustaka

Carmona, M. (2003). Public Places- Urban Spaces, The Dimension of Urban Design. Routledge Johnson, R, 2017, The Ultimate History of Healthy Eating, diunduh 20 Agustus 2019, < https://theculturetrip.com/north-america/usa/articles/the-ultimate-history-of-healthyeating/

Mclaren, D., Agyeman, J. (2015). Sharing Cities: A Case for Truly Smart and Sustainable Cities. Cambridge, MIT Press

Oldenburg, R. (1989). The Great Good Place: Cafes, coffee shops, bookstores, bars, hair salons and other hangouts at the heart of community. Philadelphia: Da Capo Press.

Story, M. (2007) Creating Healthy Food and Eating Environments: Policy and Environmental Approaches, diunduh 20 Agustus 2019, <https://www.annualreviews.org/doi/full/10.1146/annurev.publhealth.29.020907.090926

Sustainable Development Goals, 2019, Goal 3:Kesehatan yang baik dan kesejahteraan, diunduh 20 Agustus 2019, <https://sustainabledevelopment.un.org/sdg3 
